Status Report 2016-2019

\title{
Ore Deposit Modeling: The Current Indian Scenario
}

\author{
M K PANIGRAHI ${ }^{1, *}$ and K L PRUSETH ${ }^{2}$ \\ Department of Geology \& Geophysics, IIT Kharagpur 721 302, WB, India
}

(Received on 31 August 2019; Accepted on 01 October 2019)

\begin{abstract}
This article attempts to summarize developments made over the past half a decade's time in the field of Ore Geology in India with a special attention to 'modeling of ore forming processes'. Some of the well-known metallogenic provinces/ metallotects debated for quite some time on the genesis of mineralization have been reviewed. It is observed that there has been a significant development with the key information coming from microanalytical data (furnishing age data as well as key chemical parameters) of ore and alteration minerals and stable isotopic data on ores from many deposits in these terranes giving rise to emergence of new ideas.
\end{abstract}

Keywords: Singbhbum; Aravall-Delhi Fold Belt; Dharwar Craton; Granite-Ore; Sulfide Melt

\section{Introduction}

Efforts to model ore forming processes in the Earth's crust have been quite intense and relentless over the past decades amongst ore geologists all over the world. There have been no bounds to what principles, methodology and tools could be applied to understand processes that result in the formation of any ore deposit of any metal in the crust, the emphasis being more on base $(\mathrm{Cu}, \mathrm{Pb}, \mathrm{Zn})$, precious $(\mathrm{Au}, \mathrm{Ag}, \mathrm{PGM})$, rare metals (Sn, W, Ta, Nb, Zr, Hf) and metals of strategic importance (U, Th, REEs). An exhaustive review of what actually is going on, is beyond the scope of this short article and we shall be restricting ourselves to a few and that too, the progress made on Indian ore deposits in the recent past. The review is in no way exhaustive and is limited to the knowledge of the authors on work of ore genesis in the Indian context. The review is also not intended to offer any criticism or agreement to ideas presented by workers on Indian ore deposits.

Ore deposit modeling is attempted with the ultimate objective of formulating criteria for exploration or more precisely 'target delineation' in greenfield, as well as brown field exploration, with the concept of 'mineral systems' gaining popularity (see Hagemann et al., 2016 for a brief review) and currently being adopted by many workers. Such exercises at the moment are carried out more for base, precious, rare and strategic metals. In order that a model for ore genesis of any deposit be put in the perspective of 'mineral system', regionally operative 'critical processes' and locally operative 'constituent processes' need to be identified and quantified if possible. In this context, it would be worthwhile to recall that the fundamental issues that need to be addressed while modeling ore deposits are (i) source of metal(s), (ii) source of fluid, (iii) mechanism of mobilization - transport of the metals and (iv) mechanism of deposition of metals, with the fourth point being invariably associated with identification of features that are unequivocally the result of depositional process/environment.

Already discovered resources of abundant metals like $\mathrm{Fe}, \mathrm{Mn}, \mathrm{Al}, \mathrm{Cr}$ are too plenty to warrant any specialized exploration program and in turn to look for models of their genesis. In the Indian context, with no much of breakthrough in exploration, the resources of these metals are still restricted to a few metallogenic provinces in the Singhbhum Craton (U), Delhi and Aravalli Fold Belts $(\mathrm{Cu}, \mathrm{Pb}, \mathrm{Zn})$ and auriferous schist belts of Dharwar Craton ( $\mathrm{Au}, \mathrm{Ag})$. Granitoids have always been known to be carriers of many metals $(\mathrm{Cu}, \mathrm{Mo}, \mathrm{Au}, \mathrm{Sn}, \mathrm{W}, \mathrm{U})$ and there are

*Author for Correspondence: E-mail:mkp@iitkgp.ac.in 
vast tracts of granitoids in all Precambrian terranes in India that are yet to be evaluated for their metallogenic potentials. While most granitoids of the Indian shield are reported to have scanty mineralizations (trans Aravalli igneous province, the Bundelkhandgranitoid complex to name a few) the Malanjkhandgranitoid complex has been the most productive so far, producing the major share of copper in the country. Since the granite systems are most studied ones both through experiments and theoretical formulations (see Pandit et al., 2019 for some important references on work done by international experts), there are enough scopes of attempting quantitative ore genetic modeling as would be discussed in one of the sections. We discuss developments in understanding of ore forming processes under headings of broad ore provinces and will touch upon salient contributions made during the recent past. Experiment on metal-sulfur systems now is more targeted towards better understanding of partial melting of sulfide ore assemblages to explain occurrence of enriched zones in metamorphosed ore bodies. Such experiments are carried out at very few places with significant contributions by Indian ore geologists justifying a separate heading. This review covers development made in the field of ore genesis over the past five years.

\section{The Singhbhum Craton Scenario}

The Snghbumcraton with multiple ore provinces of ferrous (Fe, $\mathrm{Cr}, \mathrm{Ni}, \mathrm{PGM})$ and nonferrous $(\mathrm{Cu}$ and associated metals, $\mathrm{Pb}-\mathrm{Zn}$ ) metals, phosphorus, $\mathrm{Au}$ and REE (U) mineralizations, have been investigated quite extensively in the past.

Pal and Bhowmick (2015) studied fluid inclusions in apatite from U-bearing quart-magnetite-apatite veins from Turamdih, (on the Singhbhum Shear Zone). They inferred apatite precipitation from a moderately high saline and high temperature $\left(\sim 450^{\circ} \mathrm{C}\right)$ fluid that evolved with mixing with a lower salinity and lower temperature fluid towards uraninite - monazite precipitation and ascribed basinal fluid as the source. Recently Pant et al. (2019) have concluded an 'epithermal' origin of uranium mineralization from many localities in the SSZ based on mineral chemistry of chlorite (chlorite geothermometry and other deduced chemical parameters). They deduced a restricted range of temperature $\left(\sim 315-355^{\circ} \mathrm{C}\right)$ and visualized a fluid mixing model comparing with world occurrences from Australia, Czech Republic and Canada and believe that their model will help in further exploration of Uranium in the area.

In the context of uranium, recent reports of occurrence of mineralization of QPC (Quartz-Pebble Conglomerate) affinity, hitherto unknown in the Singhbhum craton, are noteworthy. They have been reported from different parts of the Iron-Ore cratonGorumahisani-Badampahar schist belt (Chakravarti et al., 2018), Mahagiri quartzite, Daitari Basin (Mukhopadhyay et al., 2016) and western margin of the Iron Ore Craton (base of the Darjing Group overlying the Bonai Granite) (Kumar et al., 2017). Chakravarti et al. (2018) describe basal conglomerate horizon (base of the Dhanjori basin) of 2-3 km strike length in the Gorumahisani-Badampahar schist belt and ascribe a modified placer origin of Au akin to the Witwatersrand situation. The conglomerate horizon has detrital chromite, zircon, rutile, monazite, pyrite and other sulfide minerals with uranium concentration up to $23 \mathrm{ppm}$ and gold mostly in the arsenian pyrite. Kumar et al. (2017) described QPC in the western margin of Bonai granite in the western part of the Iron Ore province, that extends for strike length of $8-10 \mathrm{~km}$. The QPC show high concentrations of $\mathrm{U}$ (average $38 \mathrm{ppm}$, with values as high as $167 \mathrm{ppm}$. They compare the Bonai QPC to world occurrence (Witwatersrand S A and Eliot Lake, Canada) and project it as a target for future exploration for Uranium. The 3.03 Ga Mahagiri Quartzite, lying unconformably over the Singhbhum Granite was described by Mukhopadhyay et al. (2016) as including a QPC at the lower part with detrital uraninite. They surmised a $>3.0 \mathrm{Ga}$ paleoplacer akin to Witwatersrand and deduced post deposition metamictization and alteration causing variable concentration of uranium in them.

The Sukinda, Boula-Nuasahi ultramafic complexes have been for long studied for their PGM potentials and mechanism of enrichment of the same metals. Prichard et al. (2018) described PGM mineralogy in the magnetite layers in the upper stratigraphic level of the Nuasahi complex. They inferred a sulfur saturation stage in the melt that gave rise to PGM-sulfide mineralization with later introduction of As and Sb. They further commented that the Nuasahi complex is a result of differentiation of a boninitic parent magma that gave rise to PGM- 
rich chromitite layers at three stratigraphic levels and such sill like intrusions with chromitite are likely to be PGM-rich. Mondal et al. (2019) highlighted the PGM geochemistry in the chromititeand the gabbrocemented breccia in the Sukinda complex and inferred them to be product of fractional crystallization of parent boninitic magma. They inferred early crystallization of IPG (Ir, Os, Ru) minerals under low fugacity of sulfur (and S-under saturated) conditions that were incorporated within late crystallizing chromite crystals. They inferred that the Sukinda and Nuashai complexes are comparable in their PGM characteristics of the host gabbroic breccia.

As far as the BIFs and base metal mineralizations in the Singhbhum craton are concerned, it is in status quo and attentions are more focused on uranium and PGM in the ultramafic complexes.

\section{The Dharwar Craton (Gold) Scenario}

The major part of debate on genetic model of lodegold deposits in the Dharwar craton is the 'metamorphogenic' versus 'magmatic' origin of auriferous ore fluid (Bhattacharya and Panigrahi, 2015). Precise age relationship between the granitoids and Au mineralization is one of the important points of concern. However, age dating of mineralization has been indirect so far (minerals in the alteration zones) and a direct dating on gold from any of the deposits is still lacking. The magmatic model looks attractive to many since there are many experimental results on solubility of gold in an oxidized Cl-rich fluid that usually evolves from granitic magma in a meltfluid regime. Any direct demonstration of mobilization of the metal during metamorphism (solid-fluid regime) is lacking as yet. The Dharwar craton with prolific metamorphosed greenstones (schist belts) and even more prolific granitic activities raise the possibility of a dual origin of the ore fluid as has been suggested by some previous workers (see Pandit et al., 2019 for references). The possibility of such dual origin usually makes any attempt to quantify the mineralization process (quantity of metal that could be available) difficult, other than the fact that granitoids in the Dharwar craton are also of multiple phases. A brief picture of the current scenario is given in the following paragraphs.

Chinnasamy and Mishra (2017) deduced the condition of deposition (decreased solubility) of gold due to decrease in fugacity of oxygen, manifested in graphite-bearing inclusions in the Au-ore in Jonnagiri gold camp. Kesarwani et al. (2019) on the other hand are of the opinion that the ore fluid at Jonnagiri gold camp was magmatic / juvenile based on detailed $\mathrm{O}, \mathrm{S}$ and $\mathrm{C}$ isotopic signatures in gold-quartz-carbonatesulfide veins. They worked out the fluid/rock ratio during hydrothermal event and deduced a low value and thus inferred insignificant disturbance to the pristine ore fluid isotopic signatures. Hazarika et al. (2016) furnished detailed mineral (scheelite, fluorite, tourmaline from two distinct generations) and bulk rock analysis of REEs and other trace elements from the Hutti gold deposit and concluded a metamorphogenic signature of the auriferous ore fluid in more than one pulse without much of contrast in its characteristics. While the tourmaline chemistry from the Uti gold camp (in proximity to the Yellagatti granite) were interpreted as indicative of metamorphogenic, tourmaline chemistry at Hira Buddini gold camp was inferred to be a manifestation of a magmatically derived, oxidizing high salinity fluid (Hazarika et al., 2015). Sahoo et al. (2018) carried out fluid inclusion studies on the Au-bearing veins along with lithogeochemistry of the hydrothermally altered rocks. They deduced a pressure variation of 2.05 to 4.36 kilo bars from carbonic inclusions (although they speculated the carbonic inclusions to be a result of differential loss of water from inclusion cavities) and temperature deduced from deformation signature of quartz $\left(500^{\circ} \mathrm{C}\right)$. They ascribed the pressure variation to change of nature of pressure at depths of $\sim 14 \mathrm{~km}$ and inferred a mixed matamorphogenic - magmatic parentage for the ore fluid.

Bhattacharya and Panigrahi (2017) and Pandit et al. (2019) presented detailed comparison of fluid inclusion characteristics in the ore regime and granitoids (matrix quartz and quartz/quartzofeldspathic veins) in the Ramagiri and Penakacherla schist belts. A granite-gold connection could be very convincingly established through heterogeneous fluid inclusion assemblages, P-T estimates in both regime and change in oxidation state of the fluid from the granitoid-domain to schistose domain through fluidrock interaction was discussed by them. Recently, Pal et al. (2019) generated important information on fluid characteristics (through fluid inclusions and isotopic make up of $\mathrm{C}, \mathrm{O}$ and $\mathrm{S}$ ) and alteration mineralogy in the Chigargunta and Bisanatham gold 
camps in the South Kolar Schist belt. They deduced fluctuating pressure conditions due to fault valve mechanism (as believed to have operated in many gold camps of EDC) and preferred a metamorphogenic origin of the ore fluid. However, they kept the possibility of a magmatic origin of the ore fluid open, based on S-isotope data.

The schist belts of Western Dharwar craton are also under active exploration and many gold prospects are currently active in the Gadag and Chitradurgaschist belts. Swain et al. $(2015,2018)$ have been advocating for a magmatic/mantle source of ore fluid and negating metamorphogenic origin, based on isotopic make up of $\mathrm{C}, \mathrm{O}$ and $\mathrm{S}$ measured from Au-quartz-carbonate veins and Au-quartz-sulfide veins.Ganguli et al (2016) report native gold bearing quartz veins associated with Kunderkondameta volcanics (boninitic) and sulfide lenses in BIF in different localities in the Shimoga schist belt of the western Dharwar craton. Based on the detailed REE geochemistry they ascribe a metamorphogenic source of ore fluid in the metavolcanics. Au in BIF is ascribed to 'epigenetic epithermal' process involving interaction of reduced S-rich auriferous hydrothermal fluid with the BIF.

\section{The Cu-Pb-Zn Deposits in Delhi and Aravalli Fold Belts}

The Aravalli-Delhi fold belts are the major repositories of $\mathrm{Cu}-\mathrm{Pb}-\mathrm{Zn}$ resources and have been producing these metals over the past several decades. The Khetri Deposit in the North Delhi fold belt and the Zawar, Rajpura-Dariba and Agucha deposits in the Aravalli fold belts have been studied by Indian workers in the past. However, their genetic affinity has remained unresolved as yet. A brief review of current developments is furnished here.

The copper deposit in Khetri is predominantly hosted by amphibole bearing feldspathic quartzite and garnetiferous chlorite schist/quartzite. Based on the mode of occurrence, geochemistry, textural and elemental composition of amphiboles, the demonstration of ore mineralization study has been initiated (Baidya et al. 2017). The association of veins and pocket deposits of amphiboles suggests its hydrothermal origin and their radial growth and the undeformed nature of veins indicate an epigenetic origin (Baidya et al. 2017). Moreover, the cross cutting relationships between the veins along with the mineral replacement textures and the differences in major and trace elemental composition advocate the fact that there are different types of amphiboles deposited in a series of fluid rock interaction events.

Baidya et al. (2017) studied $\mathrm{Na}$ and $\mathrm{Cl}$ rich mariolitic scapolite found associated with amphiboles near the veins and proposed that the high saline fluid is responsible for amphibole crystallization. They also describe about the source of ore mineralization. Being felsic in composition, the host rock is unlikely to contain high concentration of $\mathrm{Cu}, \mathrm{Fe}, \mathrm{Co}$, Ni indicating an extraneous source of mafic rocks spatially associated with these deposits for the sulfide deposition in this area.

Baidya et al. (2018) studied two very rare Co bearing phases-cobalt pentlandite and cobaltianmackinawaite from Madan Kudan copper deposit which shows that the investigated area contains a high ratio of $\mathrm{Co}$ : Ni. Since mafic rocks generally contain a higher amount of Ni compared to $\mathrm{Co}$, it contradicts the condition found in the study area and therefore, they concluded that the high $\mathrm{Co}: \mathrm{Ni}$ ratio in the sulfide mineral is due to presence of $\mathrm{Cl}$ rich hydrothermal solution. As Co is much more soluble in this than $\mathrm{Ni}$, they inferred that there is transport of metals from mafic source by $\mathrm{Cl}$ rich solution, suggesting an involvement of saline fluid in this deposit.

The chondrite-normalized REE pattern studied by Baidya et al. (2017) by using geochemistry of different amphibole types shows that the amphibole which is close to sulfidemineralization shows less negative Eu anomaly and more negative Ce anomaly and hence, evidence that these amphiboles are a result of oxidizing nature of the parental fluid. Yet another evidence of involvement of oxidizing fluid is indicated by the presence of uraninite in the sulfide veins. Near the vein, the amphiboles, which are associated with sulfidemineralization, contains higher $\mathrm{Fe}^{3+}$ than $\mathrm{Fe}^{2+}$ in comparison to other amphiboles indicating a more oxidizing condition of deposition resulting in the reduction of the oxidized fluid, which leads to the precipitation of $\mathrm{Cu}$ sulfide and uraninite. Hence, they concluded $\mathrm{U}$ transport in oxidizing fluid and deposition near the vein under reducing condition. The veins with rare Co rich phases contain magnetite and pyrrhotite and rarity of pyrite suggests that the fluids from which 
the vein and the minerals crystallized was of low sulfur fugacity and thus favors the condition for sulfide precipitation.

Baidya et al. (2017) also studied the textures of all the amphiboles from which they inferred the sequence of hydrothermal alteration/metasomatism, which proceeded in the direction of $\mathrm{Na}-\mathrm{K}(-\mathrm{Ca})$ enrichment. Khetri belt is associated with $\mathrm{Cl}$ rich hydrothermal solution at low sulfidation environment, high Co: Ni ratio in sulfidemineralization, abundance of magnetite and presence of $\mathrm{Na}-\mathrm{K}(-\mathrm{Ca})$ alteration, which are thus the main characterization of an iron oxide $\mathrm{Cu}-\mathrm{Au}$ deposit. Hence, they concluded that mineralization at Khetri is more akin tothe IOCG type of deposit.

Ilyas et al. (2017) carried out fluid inclusion studies on quartz associated with massive ores of the Paleoproterozoic carbonate-hosted Pb-Zn Deposit at Balaria, Rajasthan. Fluid inclusions data along with Ramanspectra indicated variability in molecular proportions of $\mathrm{CH}_{4}, \mathrm{~N}_{2}$ and $\mathrm{CO}_{2}$ and were interpreted by them as an evidence for mixing of pulses of a regional fluid with a local fluid and reactions with graphitic and, carbonate rocks at the site of deposition. The low salinity of fluid inclusions in the quartz contrasts with quartz from other higher-salinity fluids reported from MVT deposits. Lack of Raman peaks of $\mathrm{SO}_{4}{ }^{2-}, \mathrm{HS}^{-}, \mathrm{H}_{2} \mathrm{~S}_{\mathrm{aq}}$ and $\mathrm{H}_{2} \mathrm{~S}_{\mathrm{g}}$ raises questions as to whether they represent ore-fluids responsible for the massive ore formation.

\section{The Granite-Ore Scenario}

Metallogeny associated with granitoids has been one of the most challenging areas of ore genesis. Granitic magmas behave differently in different tectonomagmatic settings resulting in wide spectrum of pluton geometry dictated by the difference in rheological contrasts with the surrounding rocks in which they are emplaced. Being enriched with volatiles $\left(\mathrm{H}_{2} \mathrm{O}, \mathrm{CO}_{2-}\right.$, S-species, halogens $)$ the crystallization evolution is sensitive to the $\mathrm{P}-\mathrm{T}$ regimes of emplacement giving rise to many possibilities of evolution of the magmatic-hydrothermal stages and morphology of resultant mineral deposits. The Precambrian granitoids exposed in many cratonic blocs in the Indian shield are quite intriguing compared to their younger analogs in active destructive continental margins.
The Malanjkhand copper deposit hosted within the Malanjkhandgranitoid complex has been one of the most debated one as regards to its genetic affinity (see Pandit et al., 2019). There has been a strong opinion on the deposit being a 'porphyry-type' based on the petrology and tectonic affinity of the Malanjkhandgranitoid, without any discussion on the ore geological aspects of mineralization (Asthana et al., 2016, 2018). Pandit et al. (2019) attempted a quantitative genetic modeling of copper and molybdenum mineralization associated with the Malanjkhand Granodiorite (MG). With the premise that a late-stage fluid evolving from the granitic magma, irrespective of the physical state (depth of emplacement) could partition metals andgive rise to mineralization, they attempted computing efficiency of removal of $\mathrm{Cu}$ and $\mathrm{Mo}$. The parameters considered are (i) initial water and halogen contents of the magma computed from bulk and mineral chemistry of apatite, (ii) melt versus fluid partition coefficients of the metals available from experiments (see Pandit et al., 2019 for references and details) and (iii) intensive parameters estimated from mineral chemistry of apatite, amphibole and plagioclase. They approximated the total mass of Malanjkhand Granodiorite (shape and depth estimates coming from rheological parameters constrained from bulk chemistry) and arrived at maximum possible tonnage of copper and molybdenum of the deposit and compared them with calculated tonnage from the presently working mine. They discussed the merits and shortcomings based on the limitations of the formulations used. The model of course did not take into account certain aspects such as the rate of ascent of the Malanjkhand pluton. Integration of ascent rate could possibly give a more accurate path of evolution of the late stage fluid exsolved from the granitic magma. Such type of quantitative genetic model for mineralization is arguably the first attempt in this regard and is very much awaited for other granitic bodies for the evaluation of their metallogenic potentials. For example, the Bundelkhand massif and vast granitic terranes in the Bastar Craton are yet to be evaluated for their metallogenic potentials. In case of both Malanjkhand and Bundelkhand, the model of ore genesis would remain incomplete without explaining formation of 'quartz reefs' that indicate extensive mobilization of silica. A precise quantitative model for such an extensive mobilization of silica need to be 
worked out for the formation of Malanjkhand quartz reef and also could be applied to other granitic terranes.

\section{Ore Genetic Insights from Melting Experiments}

Successful exploration and exploitation of ore deposits depends upon the conception of appropriate models that can accurately account for the genesis, remobilization and localization of ores. Ore deposits represent the epitome of concentration processes that scavenge, transport and segregate sparse metals contained in a volume of rock. These may involve prolonged large scale cycles of various physical and chemical processes of magmatic, sedimentary and metamorphic nature. In spite of the clear understanding on the possibility of anatectic melting due to metamorphism, it was not adequately recognized that partial melting of preexisting sulfide ore deposits undergoing metamorphism could also be an important ore genetic process, although there were enough experimental studies demonstrating the possibility of existence of sulfide melts at lower temperatures appropriate even to lower green schist facies metamorphism, particularly in systems involving low-melting chalcophile elements such as, $\mathrm{Sb}, \mathrm{Bi}, \mathrm{Ag}$, etc. Once accepted, the possibility of partial melting of a preexisting sulfide ore deposit can easily explain and predict several features such as distinct paragenesis of minerals of certain elements and their localization within the ore body. Mechanical and hydrothermal remobilization of ores have been considered the predominant modifying processes in the past because of the difficulty in identifying features suggestive of melting of natural sulfide assemblages. This emanates particularly from the fact that reequilibration and re-crystallization of sulfide phases are facilitated by high reaction kinetics in sulfide systems. This is the reason there is no report on finding ever of any sulfide glass, which would have made conceiving and incorporating anatexis and partial melting of sulfides more natural and intuitive when formulating ore genetic models. This is important, as partial melting of sulfides leads to the partitioning of selected rare elements into the melt, which may segregate to preferred low-stress structural sites or even completely separate from the parent ore body facilitated by its very low viscosity.

\section{Evidence on Sulfide Partial Melting and Melt- Assisted Ore Remobilization}

Partial melting and melt-assisted ore remobilization have been established in a number of sulfide ore deposits and the number is steadily growing (see Pruseth et al., 2016; Govindarao et al., 2017, 2018 for reference to literature). A direct approach to check if partial melting had occurred is to verify with a representative ore assemblage, which can be heated up to the temperature at which a particular ore deposit was metamorphosed and ascertain the presence of any melt after quenching. This approach can be used efficiently if there is available an accurate estimate of the ore minerals. However, to get such estimates is difficult as some of the components may be removed from the original ore assemblage during metamorphism and remobilization, and the observable assemblage may represent only the refractory residue after remobilization. Also the true composition of the remobilized ore is difficult to establish, as the ore melt may undergo fractionation while it moves through the veins in the host rock. Tiny multi-mineral inclusions, the presence of which has been suggested as one of the diagnostic criteria indicating sulfide partial melting, may provide the closest possible composition of the sulfide melt and indicate the minimum temperature of melting that is the temperature of their homogenization. Low dihedral angles between major sulfide mineral phases and the accumulation of minerals of low-melting chalcophile elements (LMCE) such as $\mathrm{As}, \mathrm{Sb}, \mathrm{Bi}, \mathrm{Ag}, \mathrm{Te}$, etc. in low-stress regions are the major criteria evidencing sulfide partial melting. The latter can be verified in experimental studies.

Hydrothermal processes have remained the most predominant mechanism by which ores are remobilized. However, there is a need for assessment of remobilization through sulfide melts that result from anatexis of preexisting ore bodies. Experimental studies show that sulfide melts, especially those containing the semimetals, can exist at low enough temperatures overlapping with the range of temperatures in which hydrothermal processes operate. Also considerable aqueous fluid can be dissolved in a sulfide melt and may exsolve during cooling causing hydrothermal remobilization of ore, simultaneously with or closely after melt-assisted remobilization. It may be difficult in such cases to extricate the signatures of one mode of ore 
remobilization from those of the other. It is possible that both hydrothermal and melt-assisted ore remobilization could have predominated and graded into each other at different stages during the evolution of an ore deposit undergoing metamorphism.

\section{Relevant Experimental Studies on Sulfide Partial Melting}

Pruseth et al. (2016) demonstrated partial melting to have taken place in the Indian polymetallic sulfide deposit of Rajpura-Dariba in the state of Rajasthan, which was metamorphosed at 580-600 ${ }^{\circ} \mathrm{C}$ and 5.5-6 $\mathrm{k}$ bar and argued that the availability of higher amounts of S, derived from the breakdown of barite, facilitated melting. The sulfide partial melt tends also to be highly enriched in $\mathrm{Cu}$ (Fig. 1) in addition to being $\mathrm{Pb}$ abd $\mathrm{Zn}$ rich. When $\mathrm{Cu}$ is present, the further presence of $\mathrm{Ag}$, $\mathrm{Sb}$ and As may promote melting in sulfide deposits at still lower temperatures and play an important role in ore remobilization. During metamorphism and partial melting elements such as $\mathrm{Ni}$ and $\mathrm{Co}$, contained in pyrrhotite and pyrite, may be incorporated in the melt and concentrate in the last fraction of the melt when fractionation takes place during cooling (Pruseth et al., 2016). Minerals like breithauptite (NiSb), nisbite $\left(\mathrm{NiSb}_{2}\right)$ and ullmannite (NiSbS), which are commonly associated with magmatic $\mathrm{Cu}-\mathrm{Ni}$ sulfide deposits, thus may be encountered in base metal sulfide deposits,

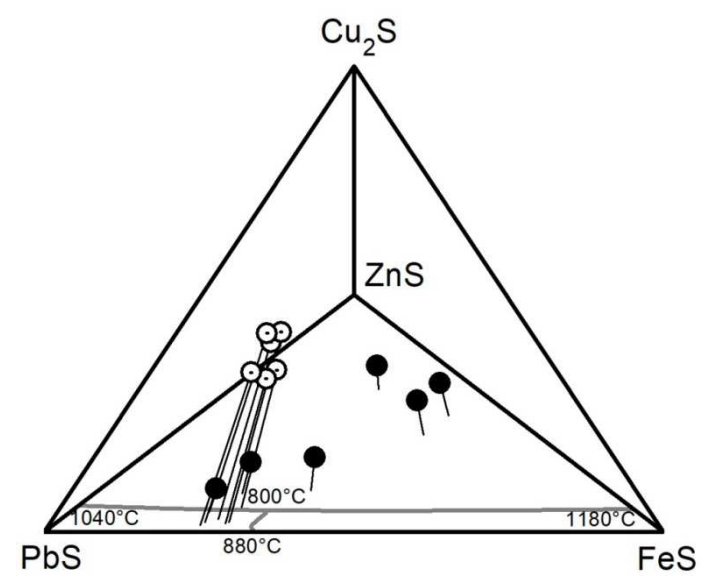

Fig. 1: Phase diagram showing the effect of incorporating $\mathrm{Cu}_{2} \mathrm{~S}$ in the system Pbs-FeS-ZnS at $600{ }^{\circ} \mathrm{C}$ (after Pruseth et al., 2014). A quaternary eutectic rich in $\mathrm{PbS}$ and $\mathrm{Cu}_{2} \mathrm{~S}$ is indicated. The eutectics obtained by Mavrogenes et al. (2001) in the system PbS-FeS-ZnS are also indicated. The filled symbols represent bulk run composition and the open symbols, the melt composition. The length of sticks are proportional to the corresponding $\mathrm{Cu}_{2} \mathrm{~S}$-contents which have undergone partial melting. Through experiments involving $\mathrm{Ni}, \mathrm{Sb}$ and $\mathrm{Ag}$, Govindarao et al. (2017) have demonstrated the possibility of the existence of immiscible melts with Ag-poor and Agrich compositions and that of a low-temperature melt having a wide range of composition, from which breithauptite may crystallize at temperatures appropriate to middle amphibolite facies metamorphism. In a further experimental study, Govindarao et al. (2018) have shown that the very common chalcopyrite disease texture in sphalerite may be produced as a corollary to sulfide partial melting and may be used as an indicator of partial melting in the context of metamorphosed sulfide deposits.

\section{Partial Melting in Indian Sulfide Ore Deposits}

The polymetallic sulfide deposit of Rajpura-Dariba, Rajasthan featured in the list of metamorphosed sulfide deposits where partial melting of sulfides was suspected to have taken place. In fact partial melting of ore deposits and ore remobilization due to partial melting may have been prevalent in the entire RajpuraDariba-Bethumni metallogenic belt. At RajpuraDariba, the existence of both a stratiform concordant and a strata-transgressive discordant ore facies and the presence of veins filled by sphalerite containing inclusions of euhedral pyrite in this deposit has been explained earlier (see Pruseth et al., 2016 for referencs) as the result of almost simultaneous crystallization of pyrite and sphalerite from a sulfide melt. They experimentally demonstrated that even with the presence of high $\mathrm{Cu}$ and excess $\mathrm{S}$, the $\mathrm{ZnS}$-content of the sulfide melt is limited to a maximum of $10 \mathrm{~mol} \%$. Thus. it is probable that early fractional crystallization of pyrite and sphalerite from a sulfide melt may have taken place. Alternatively, some unknown disequilibrium process may have been responsible for the production of a $\mathrm{Zn}$-enriched sulfide melt enabling remobilization of sphalerite.

In summary, sulfide partial melting during metamorphism of base metal sulfide deposits could have remobilized sulfide ores and would have played a role in the genesis of ore deposits. However, the range of possibilities, including the possibility of disequilibrium processes accompanying such melting, is largely unknown. The knowledge of occurrence of sulfide partial melting and that of the factors influencing this process of melting is essential for 
modeling ore deposits for successful exploration and exploitation thereof.

\section{Epilogue}

In addition to the major metallogenic provinces of the Indian shield, there are other prospects of gold having potentials of being economic or already producing in minor quantities. The Bhukia gold prospect in the Aravalli Fold belt is one such promising gold field where gold mineralization occurs in albitites and carbonates in schistose country rocks. Mukherjee et al. (2017) studied mineral chemistry of magnetite and apatite associated with gold-sulfide veins and suggested them to be of IOCG - IOA (iron oxide apatite) affinity. Uranium mineralization in the Samarkiya area in the central Aravalli Fold belt is another piece of study by Ozha et al. (2017) where they visualize mineralization to be associated with multiple phases of metamorphism, even a hitherto undated phase $\sim 1.35$ Ga through EPMA dating of uraninite.

As would be evident from discussions in the forgoing sections, developments in understanding of ore deposit formation has been quite significant in the recent past in terms of quality that has been possible because of availability and access to advanced analytical techniques, specifically the micro beam techniques and IRMS equipment generating data on stable isotopes. Although qualitative in many cases, models proposed will go a long way in formulation of

\section{References}

Asthana D, Kumar H, Balakrishnan S, Xia, Q and Feng M (2016) An early Cretaceous analogue of the $2.5 \mathrm{Ga}$ Malanjkhand porphyry copper deposit, Central India Ore Geol Rev 72 1197-1212

Asthana D, Kumar S, Vind A K, Zehra F, Kumar H and Pophare A M (2018) Geochemical fingerprinting of $\sim 2.5$ Ga forearc-backarc related magmatic suites in the Bastar Craton, India J Asian Earth Sci 157 218-234

Baidya A S, Sen A and Pal D C (2018). Textures and compositions of cobalt pentlandite and cobaltianmackinawite from the Madan-Kudan copper deposit, Khetri Copper Belt, Rajasthan, India Journal of Earth System Science 12756

Baidya A S, Paul J, Pal D C and Upadhyay D (2017) Mode of occurrences and geochemistry of amphibole in the KolihanChandmari copper deposits, Rajasthan, India: insight into exploration strategies. Models of ore genesis need not always necessarily be traditionally geologic fractal geometry based models reveal information that have tremendous exploration implications. Swain et al. (2019) is a noteworthy effort in this regard and it is hoped that such models in combination with traditional ore genetic models will prove to be far more useful. As it stands now, controversies galore in nearly all deposits in the Indian shield and we have to see how and when they are going to be resolved. The onus is on Indian ore geologists to work out genetic models which are integrable to both data driven and knowledge driven models of mineral exploration and to serve a better purpose.

\section{Acknowledgements}

We thank Prof. Somnath Dasgupta and Prof. D M Banerjee for inviting us to contribute to this volume of the Proceedings of INSA and we immensely thank Prof. Dasgupta for his patience in tolerating the inordinate delay in submitting this article. We acknowledge valuable inputs from our graduate students Rajeswar Das and Arkodeep Sengupta.

\section{Disclaimer}

We regret in advance for any omission of contributions made by Indian workers in the fields coming under the theme of this article and geologic domains covered by us. We assure that if there is any, it is inadvertent.
Bhattacharya S and Panigrahi M K (2017) Volatiles associated with granitoidintrusives around orogenic gold deposits in Ramagiri and Penakacherla Regions of Eastern Dharwar Craton, south India J Geol Soc India 90 569-576

Bhattacharya S and Panigrahi M K (2015) Source of ore fluid in lode gold deposits of Eastern Dharwar Craton: An intricate issue J Ind Inst Sci 95 173-186

Chakravarti R, Singh S, Venkatesh A, Patel S K and Sahoo P R (2018) A Modified Placer Origin for Refractory Gold Mineralization Within the Archean Radioactive QuartzPebble Conglomerates from the Eastern Part of the Singhbhum Craton, India Econ Geol 113 579-596

Chinnasamy S S and Mishra B (2017) Genetic implications of fluid-deposited disordered graphite and methane-rich inclusions in the Jonnagiri granodiorite-hosted gold deposit, 
Eastern Dharwar Craton, India Ore Geol Rev 89 587-593

Ganguli S, Manikyamba C, Saha A, Lingadevaru M, Santosh M, Rambabu S, Khelen A C, Purushotham D and Linga D (2016) Geochemical characteristics of gold bearing boninites and banded iron formations from Shimoga greenstone belt, India: Implications for gold genesis and hydrothermal processes in diverse tectonic settings Ore Geol Rev 73 5982

Govindarao B, Parihar R, Pruseth K L and Mishra B (2017) The occurrence of breithauptite and nisbite-like Sb-Ni phases at Sindesar-Khurd, Rajasthan, India: Implications for melt assisted sulfide remobilization Canadian Mineralogist $\mathbf{5 5}$ 75-87

Govindarao B, Pruseth K L and Mishra B (2018) Sulfide partial melting and chalcopyrite disease: An experimental study American Mineralogist 103 1200-1207

Hagemann S G, Lisitsin V A and Huston D L (2016) Mineral system analysis: Quo vadis Ore Geol Rev 76 504-532

Hazarika P, Mishra B and Pruseth K L (2015) Diverse Tourmaline Compositions from Orogenic Gold Deposits in the HuttiMaski Greenstone Belt, India: Implications for Sources of Ore-Forming Fluids Econ Geol $110337-353$

Hazarika P, Mishra B and Pruseth K L (2016) Scheelite, apatite, calcite and tourmaline compositions from the late Archean Hutti orogenic gold deposit: Implications for analogous two stage ore fluids Ore Geol Rev 72 989-1003

Ilyas M and Pandalai H S (2017) Fluid inclusion studies on quartz associated with massive ores of the Paleoproterozoic carbonate-hosted $\mathrm{Pb}-\mathrm{Zn}$ deposit at Balaria, Rajasthan: Possible evidence for fluid- mixing Journal of the Geol Soc of India 90 577-585

Kumar A, Venkatesh A S, Kumar P, Rai A K and Parihar P S (2017) Geochemistry of Archean radioactive Quartz Pebble Conglomerate and quartzites from the western margin of Singhbhum-Orissa craton, eastern India: Implications on Paleoweatheringprovenence and tectonic setting Ore Geol Rev 89 390-406

Kesarwani M, Sarangi S, Srnivasan R, George B G, Bhattacharya S and Vasudeva V N (2019) Origin of granodiorite hosted Neoarchaean orogenic gold ore deposits: Stable isotopic and geochemical constraints with example from the Dharwar craton, southern India Ore Geol Rev 110 754779

Mondal S K, Khatun S, Prichard H M, Satyanarayanan M and Ravindra Kumar G R (2019) Platinum-group element geochemistry of boninite-derived Mesoarchean chromitites and ultramafic-mafic cumulate rocks from the Sukinda Massif (Orissa, India), Ore Geol Rev 104 722-744
Mukherjee R, Venkatesh A S and Fareeduddin (2017) Chemistry of magnetite-apatite from albitite and carbonate-hosted Bhukia Gold Deposit, Rajasthan, western India - An IOCG-IOA analogue from Paleoproterozoic Aravalli Supergroup: Evidence from petrographic, LA-ICP-MS and EPMA studies Ore Geol Rev 91 509-529

Mukhopadhyay J, Mishra B, Chakrabarti K, De S and Ghosh G (2016) Uraniferouspaleoplacers of the Mesoarchean Mahagiri Quartzite, Singhbhum craton, India: Depositional controls, nature and source of N3.0 Ga detrital uraninites Ore Geol Rev 72 1290-1306

Ozha M, Pal D C, Mishra B, Desapati J and Shaji T S (2017) Geochemistry and chemical dating of uraninite in the Samarkiya area, central Rajasthan, northwestern India Implication for geochemical and temporal evolution of uranium mineralization Ore Geol Rev 88 23-42

Pal D, Chinnasamy S S, Goon S, John M M and Ghosh S (2019) Alteration mineralogy, fluid inclusions and stable isotope studies from Chigargunta and Bisanatham gold deposits, South Kolar Greenstone Belt, Dharwar Craton, India: Implications on genesis of gold mineralization Ore Geol $\operatorname{Rev}$ (in press)

Pal D C and Bhowmick T (2015). Petrography and microthermometry of fluid inclusions in apatite in the Turamdih uranium deposit, Singhbhum shear zone, eastern India-An insight into ore forming Fluid Journal of the Geol Soc of India 86 253-262

Pandit D, Bhattacharya S and Panigrahi M K (2019)-Dissecting through the metallogenic potentials of Precambrian granitoids - case studies from Bastar and Eastern Dharwar cratons India Geol Soc London Sp Pub 489

Pant S, Singh S, Sahoo P R, Kumar A, Saravanan B, Venkatesh A S, Yadav G S and Kumar P (2019) Mineral chemistry and geothermometry of chlorites in relation to physicochemical conditions of uranium mineralization in the central part of the Singhbhum Shear Zone, eastern India Ore Geol Rev 112 (in press)

Prichard H M, Mondal S K, Mukherjee R and Giles F N (2018) Geochemistry and mineralogy of Pd in the magnetitite layer within the upper gabbro of the Mesoarchean Nuasahi Massif (Orissa, India) Mineralium Deposita 53 547-564

Pruseth K L, Mishra B, Jehan N and Kumar B (2016) Evidence of sulfide melting and melt fractionation during amphibolite facies metamorphism of the Rajpura-Dariba polymetallic sulfide ores Ore Geol Rev 72 1213-1223

Sahoo AK, Krishnamurthi R and Sangurmath P (2018) Nature of ore forming fluids, wallrock alteration and $\mathrm{P}-\mathrm{T}$ conditions of gold mineralization at Hira-Buddini, Hutti-Maski 
Greenstone Belt, Dharwar Craton, India Ore Geol Rev 99 195-216

Swain S, Sarangi S, Srinivasan R, Sarkar A, Bhattacharya S, Patel S C, Pasayat R M and Sawkar R H (2015) Isotope (C and O) composition of auriferous quartz carbonate veins, central lode system, Gadag Gold Field, Dharwar Craton, India: Implications to source of ore fluids Ore Geol Rev 70305 320

Swain S K, Sarangi S, Srinivasan R, Sarkar A, Kesarwani M,
Mazumdar A and Satyanarayanan M (2018) Stable isotope (C-O-S) and geochemical studies of auriferous quartz carbonate veins, Neoarchaean orogenic Ajjanahalli and Gadag Gold Field, Chitradurga schist belt, Dharwar Craton, southern India: Implication for the source of gold mineralizing fluids Ore Geol Rev 110 456-479

Swain S K, Roy P N S, Mukherjee B and Sawkar R H (2019) Fractal dimension and its translation into gold spatial proxy Ore Geol Rev (in press). 